\title{
Anthropometric and clinical profiles of post-bariatric patients submitted to procedures in plastic surgery
}

\section{Perfil antropométrico e clínico de pacientes pós-bariátricos submetidos a procedimentos em cirurgia plástica}

Simone Corrêa Rosa ${ }^{1,2}$; Jefferson lessa Soares de Macedo, TCBC-DF1,3; Luiz Augusto Casulari²; Lucas Ribeiro Canedo3; João Vitor Almeida Marques ${ }^{3}$

\section{A B S T R A C T}

\begin{abstract}
Objective: to evaluate the profile of patients submitted to post-bariatric plastic surgery at the North Wing Regional Hospital, Brasilia, DF. Methods: we conducted a prospective, descriptive and analytical study of patients submitted to Roux-en-Y gastroplasty, and subsequently to plastic surgery, from January 2011 to December 2016. We assessed body mass index before gastroplasty and after surgery plastic surgery, postoperative complications and comorbidities. Results: we studied 139 patients (130 women and nine men), with a mean age of 41 years, who underwent 233 operations. The mean BMl at the time of plastic surgery was $27.44 \mathrm{~kg} / \mathrm{m}^{2}$. The mean weight loss was $47.02 \mathrm{~kg}$ and the mean maximum BMI was $45.17 \mathrm{~kg} / \mathrm{m}^{2}$. The mean time between bariatric surgery and plastic surgery was 42 months. The most important co-morbidities before plastic surgery were arterial hypertension (11.5\%), arthropathy (5.4\%), diabetes mellitus (5\%) and metabolic syndrome (4.3\%) (p<0.01). Of the 139 patients operated on, 76.97\% underwent abdominoplasty followed by mammoplasty (42.46\%), rhytidoplasty (17.27\%) and brachioplasty (13.67\%). Fourteen (13.08\%) patients underwent herniorrhaphy combined with abdominoplasty. We performed anchor abdominoplasty in $19.42 \%$. The rate of postoperative complications was $26.65 \%$. Conclusion: the epidemiological profile of post-bariatric patients who underwent plastic surgery was similar to that reported in the literature, except for the low rate of associated surgeries and postoperative complications. Plastic surgery in post-bariatric patients has led to an improvement in the quality of life in most of these patients.
\end{abstract}

Keywords: Bariatric Surgery. Surgery, Plastic. Abdominoplasty. Postoperative Complications.

\section{INTRODUCTION}

$\mathrm{O}$ besity is a disease of epidemic proportions, often associated with increased morbidity and mortality, as well as increased health spending, and reduced life quality and expectancy ${ }^{1}$. Safety in the performance of bariatric surgery, represented by low rates of early and late complications (venous thromboembolism, surgical reintervention, prolonged hospitalization) and a mortality rate of $0.3 \%$, together with a significant improvement in comorbidities, justify its inclusion as an important strategy in the treatment of severe obesity ${ }^{2,3}$. However, many patients are not prepared to deal with excess skin due to massive weight loss, which can lead to a decline in quality of life and an increased risk of weight regain ${ }^{4,5}$. These patients show stabilization or even decline in quality of life after the second year of gastric bypass surgery ${ }^{6}$, which can be attributed to changes in physical appearance and the decline associated with dissatisfaction with one's own body image. Repairing plastic surgery plays an important role in stabilizing the quality of life of patients with massive weight loss after bariatric surgery, maintaining the improvement of the quality of life sustained in the long term? ${ }^{7}$.

This study aims to present the anthropometric profile, the presence of comorbidities and the quality of life of post-bariatric patients submitted to procedures in plastic surgery.

\section{METHODS}

We carried out a prospective study in a public reference hospital for bariatric surgery, with individuals who underwent Roux-en- $Y$ gastric bypass and were

1 - Asa Norte Regional Hospital, Plastic Surgery Service, Brasília, DF, Brazil. 2 - University of Brasília/FEPECS, Post-Graduation Course in Health Sciences, Brasília, DF, Brazil. 3 - Superior School of Health Sciences, Medical School, Brasília, DF, Brazil. 
subsequently operated on for body contouring, from 2011 to 2016, after massive weight loss. The same staff team performed all operations at the Regional Hospital of Asa Norte, Brasília, DF.

The body mass index (BMI) was used for the diagnosis of obesity and the following criteria were used: normal weight (BMI between 18.5 and $24.9 \mathrm{~kg} / \mathrm{m}^{2}$ ), overweight (BMl between 25 and $29.9 \mathrm{~kg} / \mathrm{m}^{2}$ ), obesity grade I (BMI between 30 and $34.9 \mathrm{~kg} / \mathrm{m}^{2}$ ), obesity grade II (BMI between 35 and $39.9 \mathrm{~kg} / \mathrm{m}^{2}$ ) and obesity grade III $\left(\mathrm{BMI} \geq 40 \mathrm{~kg} / \mathrm{m}^{2}\right)^{8.9}$.

Patients with $\mathrm{BMI}>40 \mathrm{~kg} / \mathrm{m}^{2}$ and those with BMI $>35 \mathrm{~kg} / \mathrm{m}^{2}$ with associated comorbidities were submitted to bariatric surgery according to international standards. In addition, patients had previous attempts at weight loss for at least two years, absence of serious clinical diseases identified by preoperative exams, absence of severe psychopathologies, absence of illicit drug use and alcoholism, age between 18 and 65 years and ability to understand the explanations about the implications of the surgical procedure. After bariatric surgery, the patients were kept in follow-up with the multidisciplinary team until weight stabilization and control of comorbidities, when they were referred to the Plastic Surgery outpatient clinic.

The percentage of excess weight loss (\%EWL) was obtained from the following formula: weight loss after surgery / overweight $X 100$. Excess weight was calculated by subtracting the ideal weight, established for a BMl of $25 \mathrm{Kg} / \mathrm{m}^{2}{ }^{10}$, from the weight at the beginning of preoperative follow-up ${ }^{10}$. The BMI variation (delta-BMI) was calculated by the difference between the maximum BMI before the bariatric surgery and the BMl at the moment of the repairing plastic surgery.

Inclusion criteria for post-bariatric repair surgery were: weight stability for at least six months after achieving the goal of weight loss for each case; absence of illicit drug use or alcoholism; absence of moderate or severe psychotic or dementia pictures; and understanding of the need for weight maintenance and post-operative follow-up with a multidisciplinary team throughout life.

Exclusion criteria were smoking, gestational intention, weight instability with no maintenance of weight for six months, individuals who did not sign the informed consent form (ICF), patients submitted to other bariatric procedures after Roux-en-Y gastroplasty, and patients with postoperative follow-up of $<12$ months.

$$
\text { All patients received non-drug }
$$

thromboprophylaxis, such as early ambulation and lower limb bandaging. We performed bladder catheterization, with catheter removal on the first postoperative day, and prophylactic antibiotic therapy with $2 \mathrm{~g}$ of IV cefazolin on the anesthetic induction.

The variables analyzed before the restorative surgery included age, gender, weight, height, BMI before bariatric surgery, BMI before reconstructive plastic surgery, total weight loss, quality of life analysis and complication rate. After bariatric surgery, we considered comorbidities resolved when they were controlled without medication, and improved, when they were controlled by reduced doses of medication.

For the diagnosis of systemic arterial hypertension, dyslipidemias, type 2 diabetes mellitus and metabolic syndrome, were used the parameters listed in the respective guidelines of the Brazilian Society of Cardiology, currently described in the First Brazilian Guideline for Diagnosis and Treatment of Metabolic Syndrome ${ }^{9,11}$. We performed the diagnosis of hepatic steatosis using preoperative abdominal ultrasonography.

To evaluate the impact of post-bariatric plastic surgery on the quality of life of these patients, we used the BAROS (Bariatric Analysis and Reporting Outcome System) method. The Moorehead-Ardelt quality of life questionnaire consists of five questions about selfesteem, readiness for physical activity, social coexistence, readiness for work and sexual activity ${ }^{12}$. Each of the five questions in the quality of life questionnaire corresponds to five response possibilities that generate a final value for each question. The patient selected the most appropriate response for each item of the questionnaire after the body contouring repair plastic surgery. The sum of the values attributed to each of the five questions expressed the individual value of each case, ranging from -3 (lowest quality of life possible) to +3 (best quality of life possible). After that, the final values of the questionnaire were categorized into five classes of quality of life: greatly 
reduced, decreased, minimal or no change, improved and greatly improved.

The complications evaluated included hematomas, seromas, dehiscences, tissue necrosis, deep venous thrombosis and pulmonary embolism. We divided the complications into major and minor. Major complications were those requiring a new surgical procedure for hematoma drainage, seroma drainage, suturing of dehiscence areas or rehospitalization for systemic antibiotic therapy.

We performed statistical analysis with the statistical package SPSS (Statistical Package for Social Sciences) version 20.0 for Windows (SPSS Inc. Chicago, IL, USA). We described continuous variables using the mean and standard deviation, and the categorical ones, with relative frequencies. We evaluated the normality of the variables with the Kolmogorov-Smirnov test. We performed the comparisons between groups with the chisquare test for the dichotomous variables, the Student's t-test for continuous variables with normal distribution, and the Mann-Whitney U-test for continuous variables without normal distribution. The minimum significance accepted was the level of $5 \%(p<0.05)$.

We elaborated this research in accordance with the resolution of the National Health Council number 466 , of $12 / 12 / 2012$. All individuals involved in this study were informed and signed the ICF for execution consent. In the present study, there was no conflict of interest. The project was approved by the Ethics in Research Committee of the Health Department of the Federal District, with the number CAAE 52738216.5.0000.5553.

\section{RESULTS}

There were 139 patients who underwent Rouxen-Y gastroplasty, $57.55 \%$ (80 patients) by laparoscopy and $42.45 \%$ (59 patients) by laparotomy. The mean age was 41.18 years \pm 9.63 (range 22 to 66 ). As shown in table 1 , women were the most frequently operated. The majority of patients came from the Federal District. The most frequent age group was 40 to 49 years, followed by 30 to 39 years, both representing $71.3 \%$ of the casuistry. Married or stable partners were the most observed, followed by singles. Regarding schooling, patients with a median level predominated, followed by the fundamental level, both comprising $86.3 \%$ of the sample. The mean time interval between bariatric surgery and the repairing plastic procedure was $42.51 \pm 28.20$ months. Patients were submitted to plastic surgery more frequently between 25 and 48 months, followed by 18 to 24 months, both representing 74\% of the sample (Tables 1 and 2).

Table 1. Distribution by gender, origin, age groups, marital status and education level of post-bariatric patients undergoing reconstructive plastic surgery in the North Wing Regional Hospital, Brasilia, DF, from 2011 to 2016

\begin{tabular}{|c|c|c|}
\hline Variables & $\mathrm{N}$ & $\%$ \\
\hline \multicolumn{3}{|l|}{ Gender } \\
\hline Female & 130 & 93.5 \\
\hline Male & 9 & 6.5 \\
\hline \multicolumn{3}{|l|}{ Origin } \\
\hline DF & 127 & 91.4 \\
\hline Out of the DF & 12 & 8.6 \\
\hline \multicolumn{3}{|l|}{ Age (years) } \\
\hline$<30$ & 15 & 10.7 \\
\hline $30-39$ & 44 & 31.7 \\
\hline $40-49$ & 55 & 39.6 \\
\hline$=50$ & 25 & 18.0 \\
\hline \multicolumn{3}{|l|}{ Marital status } \\
\hline Married & 86 & 61.9 \\
\hline Single & 40 & 28.8 \\
\hline Divorced & 9 & 6.4 \\
\hline Widowed & 4 & 2.9 \\
\hline \multicolumn{3}{|l|}{ Schooling } \\
\hline College & 16 & 11.5 \\
\hline High school & 72 & 51.8 \\
\hline Essential & 48 & 34.5 \\
\hline Illiterated & 3 & 2.2 \\
\hline \multicolumn{3}{|c|}{ Time interval (months) * } \\
\hline $18-24$ & 40 & 28.7 \\
\hline $25-48$ & 63 & 45.3 \\
\hline $49-72$ & 25 & 18 \\
\hline$>72$ & 11 & 9 \\
\hline
\end{tabular}

* Time interval between bariatric surgery and plastic surgery. 
Table 2. Profile of the patients before the reconstructive plastic surgery.

\begin{tabular}{lcc}
\hline \multicolumn{1}{c}{ Characteristics } & Mean $\pm \mathrm{Sd}$ & Range \\
\hline Age (years) & $41.18 \pm 9.63$ & 22 to 66 \\
Maximum weight $(\mathrm{kg})$ & $119.98 \pm 23.76$ & 86 to 220 \\
$\mathrm{BMI} *\left(\mathrm{~kg} / \mathrm{m}^{2}\right)$ & $45.17 \pm 7.99$ & 35 to 88.13 \\
Final pré-plastic BMI $\left(\mathrm{kg} / \mathrm{m}^{2}\right)$ & $27.44 \pm 3.79$ & 19.38 to 47 \\
Total weight loss $(\mathrm{kg})$ & $47.02 \pm 17.28$ & 20 to 135 \\
$\%$ EWL ** & $79.15 \pm 13.01$ & 50.90 to 111.70 \\
Time interval (months) $* * *$ & $42.51 \pm 28.20$ & 18 to 252 \\
\hline
\end{tabular}

*BMI: body mass index; ${ }^{* *} \% E W L$ : percentage of excess weight loss; ${ }^{\star \star \star}$ Time interval between the gastric bypass and plastic surgery.

The mean maximum BMl before bariatric surgery was $45.17 \pm 7.99 \mathrm{~kg} / \mathrm{m}^{2}$. Table 3 shows that patients undergoing bariatric surgery were often morbidly obese, followed by patients classified as grade II obesity and both represented $100 \%$ of the sample. Before repairing plastic surgery, the mean BMl was $27.44 \pm 3.79 \mathrm{~kg} / \mathrm{m}^{2}$.
The mean percentage of excess weight loss (\%EWL) was $79.15 \pm 13.01$. We also observed that patients who underwent post-bariatric plastic surgery were more frequently overweight, followed by patients with normal BMI, both comprising $75.6 \%$ of the sample.

Table 3. Distribution of patients according to the degree of obesity determined by body mass index before the gastric bypass and before plastic surgery.

\begin{tabular}{lcc}
\multicolumn{1}{c}{ BMl $\left(\mathrm{kg} / \mathrm{m}^{2}\right)$} & Before the gastric bypass $\mathrm{n}(\%)$ & Before the plastic surgery $\mathrm{n}(\%)$ \\
\hline$<25$ (Normal) & -- & $32(23.1)$ \\
$25-29.9$ (Overweight) & -- & $73(52.5)$ \\
$30-34.9$ (Grade I) & -- & $31(22.3)$ \\
$35-39.9$ (Grade II) & $30(21.6)$ & $1(0.7)$ \\
$>40($ Grade III) & $109(78.40)$ & $2(1.4)$ \\
\hline
\end{tabular}

The difference between the maximum BMI before bariatric surgery and the BMI before repairing plastic surgery was $18.25 \pm 8.83$. Of the patients, $29.5 \%$ (41/139) presented a BMI variation greater than 20 . The mean weight loss before repair was $47.02 \mathrm{~kg} \pm 17.28$. The mean maximum weight before bariatric operation was $119.98 \mathrm{~kg} \pm 23.76$ (Table 2). The mean weight before restorative plastic surgery was $72.97 \mathrm{~kg} \pm 12 ; 33.8 \%$ $(47 / 139)$ of the patients had a weight loss equal to or greater than $50 \mathrm{~kg}$.

Table 4 shows the diseases present before bariatric surgery. We observed that the most frequent morbidities were metabolic syndrome and arterial hypertension, followed by arthropathy, depression/ anxiety and diabetes mellitus. Obstructive sleep apnea, esophagitis and dyslipidemia were the less common morbidities. 
Table 4. Distribution of patients according to the presence of associated diseases before and after gastric bypass

\begin{tabular}{lccc}
\hline \multicolumn{1}{c}{ Associated diseases } & Before gastric bypass $\mathrm{n}(\%)$ & After gastric bypass $\mathrm{n}(\%)$ & $\mathrm{p}$ \\
\hline Metabolic syndrome & $73(52.5)$ & $6(4.3)$ & 0.017 \\
Hypertension & $71(51.1)$ & $16(11.5)$ & $<0.001$ \\
Arthropathy & $56(40.3)$ & $8(5.4)$ & $<0.001$ \\
Depression/Anxiety & $55(39.6)$ & $39(28.1)$ & $<0.001$ \\
Diabetes mellitus & $50(36.0)$ & $7(5.0)$ & $<0.001$ \\
Sleep apnea & $31(22.3)$ & $2(1.4)$ & 0.008 \\
Esophagitis & $30(21.6)$ & $4(2.9)$ & $<0.001$ \\
Dyslipidemia & $29(20.9)$ & $2(1.4)$ & 0.006 \\
\hline
\end{tabular}

The vast majority of patients reported improvement or complete resolution of the various comorbidities after surgical treatment of obesity. However, as shown in table 4, some patients still had diseases by the time of the repairing plastic procedure, mainly depression/ anxiety and hypertension. The other comorbidities presented with low frequency, such as arthropathy, diabetes, metabolic syndrome, esophagitis, obstructive sleep apnea and dyslipidemia. A third of the patients (33.8\% - 47/139) had undergone cholecystectomy before repairing plastic surgery.

As for the daily number of drug pills that patients used before bariatric surgery, the mean was 4.17 \pm 3.17 . After bariatric surgery, the mean decreased to $1.75 \pm 1.33$, with statistical significance $(p<0.001,95 \% \mathrm{Cl}$ : 3.64-4.69).

Seventy-three $(52.5 \%)$ patients underwent a single plastic surgery, 49 (35.3\%), two, and 17 (12.2\%), three or more procedures. The mean number of repair procedures per patient was $1.60 \pm 0.74$ (ranging from one to four surgical procedures per patient). One hundred and twenty-three patients (88.5\%) underwent only one surgical procedure per stage, $16(11.51 \%)$ had associated operations in the same surgical procedure, that is, two or more surgical procedures per stage. Table 5 presents the procedures of reconstructive plastic surgery. We observed that the majority of patients were submitted to abdominoplasty, the classic technique being the most used, followed by the anchor technique, and both techniques represented $76.97 \%$ of the procedures in the operated patients. Six patients had incisional hernias and eight had umbilical hernias, representing $13.08 \%$ of patients undergoing abdominoplasty. We performed the herniorrhaphy along with the abdominoplasty. Table 5 also shows the techniques of mastoplasty. Mastopexy with prosthesis was the most frequently used, followed by reductive mastoplasty, and both techniques accounted for $42.46 \%$ of the procedures.

Table 5. Distribution of surgical procedures performed in post-bariatric patients operated in the North Wing Regional Hospital, Brasilia, DF, from 2011 to 2016.

\begin{tabular}{lcc}
\hline \multicolumn{1}{c}{ Surgical procedures } & $\mathrm{N}$ & $\%$ \\
\hline $\begin{array}{l}\text { Tummy Tuck } \\
\text { Classic }\end{array}$ & 80 & 57.55 \\
$\quad$ Anchor & 27 & 19.42 \\
Mastoplasty & & \\
$\quad$ With prosthesis & 44 & 31.65 \\
$\quad$ Reductive & 15 & 10.79 \\
$\quad$ Augmentation & 11 & 7.91 \\
Rhytidoplasty & 24 & 17.27 \\
Brachioplasty & 19 & 13.67 \\
Cruroplasty & 13 & 9.53 \\
Total pacients & 139 & \\
Total procedures & 233 & \\
\hline
\end{tabular}

As for the other less frequent surgical procedures, we performed facial plastic surgery (rhytidectomy) in $17.27 \%(24 / 139)$ of the patients, arms plastic surgery 
(brachioplasty) in 13.67\% (19/139), and thighs plastic surgery (cruroplasty), in $9.35 \%$ (13/139) (Table 5).

The mean weight of the flap of the abdomen removed in the abdominoplasty was $1,985.51 \mathrm{~g} \pm 1,268.32$ (range $350-7,880 \mathrm{~g}$ ). Abdominal flaps weighing 1,000 to $1,999 \mathrm{~g}$ were the most frequent, followed by those from 2,000 to $3,000 \mathrm{~g}$, both of which accounted for $70 \%$ of the sample. The flaps weighing $<1,000 \mathrm{~g}$ were $17.76 \%$ of the sample, and flaps weighing $>3,000 \mathrm{~g}, 12.15 \%$.

As for the volume of the mammary implant used in mastoplasties with prosthesis or augmentation, the mean was $268.62 \mathrm{ml} \pm 40.33$ (range 175 -355ml).

Regarding the complications of the reconstructive plastic surgery, the smaller minor were more frequent than the major ones. The overall complication rate was $26.65 \%$ (37/139). The major complication rate was $9.35 \%$ (13 patients), five cases of dehiscence with need for resection, three cases of seroma requiring reoperation, three cases of internal hernia with intestinal obstruction, and two cases of wound infection requiring treatment with intravenous antibiotic therapy. The rate of minor complications was $17.3 \%$ (24 patients), seven cases of dehiscence without need for resection, seven cases of seroma requiring repeated punctures, six cases of hematoma with drainage or spontaneous resolution, and four cases of wound infection requiring treatment with oral antibiotic therapy alone.

The mean surgical time was three hours and ten minutes, ranging from 160 to 270 minutes. We used vacuum drains in all abdominoplasty cases.

We used general anesthesia in 119 patients (85.6\%), and epidural, in 20 (14.4\%).

The mean hospitalization time was two days in $128(92.1 \%)$ cases. Only 11 (7.9\%) patients remained hospitalized for a longer period.

We followed patients for at least six months. There were no cases of deep venous thrombosis, pulmonary embolism or deaths in the present study.

Table 6 presents the assessment of quality of life after repairing plastic surgery in post-bariatric patients. We observed that more than $90 \%$ of the patients reported an improvement in the quality of life. The mean score obtained on the Moorehead-Ardelt quality of life questionnaire applied to 36 patients was 2.18.
Table 6. Distribution of patients according to the quality of life after repair plastic operation at the North Wing Regional Hospital, Brasilia, DF, from 2011 to 2016.

\begin{tabular}{lc}
\hline Classification of quality of life * & $N(\%)$ \\
\hline Much worse & $0(0)$ \\
Worse & $2(5.56)$ \\
Minimal or no change & $1(2.78)$ \\
Better & $8(22.22)$ \\
Much better & $25(69.44)$ \\
Total & $36(100)$ \\
\hline
\end{tabular}

* Score obtained from the Moorehead-Ardelt questionnaire. Distribution in five categories: much worse, score range -3.00 to -2.2 ; Worse, -2.00 to -0.75; Minimal or no change -0.50 to +0.5 ; Better, 0.75 to 2.00; and Much better, 2.25 to 3.00 .

\section{DISCUSSION}

The common sequelae of successful weight loss after bariatric surgery remain stigmatizing in the form of excess skin and soft tissues. Body contouring restorative surgery helps to promote social and psychological reintegration for these patients. In addition, restorative plastic operations after gastroplasty aim to optimize the functional results obtained by bariatric surgery by removing excess $\mathrm{skin}^{7,13}$. Restorative plastic surgery plays an important role in stabilizing the quality of life of patients with massive weight loss after bariatric surgery, maintaining the improvement of the quality of life in the long term? ${ }^{7}$.

The present study showed that the majority of the patients consisted of women, as well as other studies ${ }^{13-18}$. Likewise, the mean age of 41 years was similar to that of other works ${ }^{15-17,19}$, but below the age of 44 years in an American work ${ }^{14}$ and 48 years evidenced by other series ${ }^{13,20}$. The mean BMl before plastic surgery of $27.4 \mathrm{~kg} / \mathrm{m}^{2}$ was similar to that found by other authors ${ }^{13-17}$, but well below the BMI of $35.6 \mathrm{Kg} / \mathrm{m}^{2}$ verified by Shermak et al. ${ }^{21}$. Likewise, the mean delta-BMl of our patients, of $18.25 \pm 8.83 \mathrm{~kg} / \mathrm{m}^{2}$, was below the $20.7 \mathrm{~kg} / \mathrm{m}^{2}$ and $22.3 \mathrm{~kg} /$ $\mathrm{m}^{2}$ verified in other studies ${ }^{14,20}$. The mean weight loss before the restorative plastic surgery of $47 \mathrm{~kg}$ was similar to that verified by Kervilier et al. ${ }^{13}$ and above the 33 to $40 \mathrm{~kg}$ observed by other authors 2,18 , but below the 51 to $53 \mathrm{~kg}$ found in other studies ${ }^{15,21.22}$. The mean percentage excess weight loss (\%EWL) of $79.1 \%$ was above the 
$68.5 \%$ verified by Novais et al. ${ }^{23}$ and the $65.7 \%$ observed by Silva et al. ${ }^{10}$. Buchwald et al. ${ }^{2}$, with 10,172 subjects submitted to the surgical procedure, found a mean EWL of $61.2 \%$ after two years of follow-up.

Among the 139 patients participating in the study, there was a $98.6 \%$ reduction in the frequency of grade III obesity. Overweight individuals submitted to plastic surgery accounted for $52.5 \%$ of the sample, those with normal $\mathrm{BMI}, 23.1 \%$, and patients with residual obesity, $24.4 \%$, similar to the data of Orpheu et al. ${ }^{16}$, in which individuals with overweight represented $56.1 \%$ of the sample and patients with BMl>30 accounted for $27.5 \%$.

There was a significant reduction in comorbidities after bariatric surgery, and at the time of restorative plastic surgery, $5.7 \%$ of the patients persisted with diabetes mellitus and only $11.5 \%$ of had systemic arterial hypertension, a reduction of $77.5 \%$ of all hypertensive patients, similar to that found by other authors ${ }^{14,24}$. As for diabetes, Roux-en-Y gastroplasty proved to be very effective in controlling the glycemic levels of obese diabetics, resulting in complete remission in most patients. In our study, we found a rate of complete diabetes remission in $86.1 \%$ of patients operated on, similar to other authors that reported rates of remission ranging from $83 \%$ to $85 \%$ 2,25. In an American study, the prevalence of comorbidities was higher, reaching 32.5\% of arterial hypertension and $15 \%$ of diabetes ${ }^{20}$.

Other comorbidities associated with obesity also displayed significant decreases in the study patients, especially dyslipidemia, metabolic syndrome and sleep apnea syndrome. The remission rates of these diseases were above $90 \%$, similar to those of other works ${ }^{14,24}$. This significant improvement of comorbidities directly reflects the drop in the number of pills and medications used by patients after bariatric surgery, as evidenced in our study.

Improvement in quality of life after repairing plastic surgeries is not necessarily associated with a decrease in psychiatric symptoms, such as depression and anxiety. In the present study, the prevalence of depression/anxiety fell from $39.6 \%$ to $28.1 \%$. Even being a significant decrease in the prevalence of this comorbidity, it was a less expressive drop when compared to that of other comorbidities.
The 42-month mean time between bariatric surgery and restorative plastic surgery was similar to the 47 months seen in another national study ${ }^{17}$, but higher than the 22 months described in other studies ${ }^{20,21}$.

As for the treatment of abdominal hernias during abdominoplasty, there was no need to use meshes. These hernias are more common when reductive gastroplasty is performed by open access ${ }^{19}$. In the present study, 57.5\% (80/139) of the patients underwent laparoscopic surgery, which reduced the risk of incisional hernia.

In patients submitted to abdominoplasty, the technique chosen was determined by the type of abdominal deformity presented by each patient, taking into account the patient's' opinion and the yearnings. In case of a great transverse excess of skin flaccidity, we performed the anchor abdominoplasty. When the abdominal contour deformity had as its main component the excess of vertical flaccidity, we performed a conventional abdominoplasty with a suprapubic transversal scar.

The association of abdominoplasty with other surgical procedures is frequent. Studies indicate an association of abdominoplasty with other surgical procedures (brachioplasty and mastoplasty) in up to $40 \%$ of operated patients, without significantly increasing the rate of postoperative complications ${ }^{14,20}$.

Post-bariatric patients pose a number of challenges for the plastic surgeon. These patients often present with residual medical comorbidities, nutritional deficiencies and psychological problems, as well as complex body habits that make this group of patients at risk for postoperative complications. The overall postoperative complication rate in post-bariatric patients was $27 \%$, similar to the studies by Kervilier et al. ${ }^{13}$, but below other studies with rates ranging from 35 to $50 \%{ }^{14-}$ $16,20,21$. Suture dehiscence was the main complication, followed by seroma, as in other series ${ }^{13,14,20}$.

There were no thromboembolic events, but other studies indicate an incidence rate of $0.3 \%$ to $1 \%{ }^{16,17}$. The need for preventive measures is a constant among the authors, who recommend devices for intermittent compression of the calf intraoperatively, as well as early ambulation and reduction of surgical time ${ }^{16}$. The low rate of major complications in this study, such 
as thromboembolic events, flap necrosis and low number of reoperations may be associated with the low number of associated surgeries. Studies with the highest rates of complications generally had a higher percentage of associated procedures ${ }^{14,20}$. The association of operations leads to a longer surgical time (> 6 hours), greater blood loss and a greater need for blood transfusions, which are factors that may favor an increase in the rate of postoperative complications ${ }^{14}$.

In the present study, $88.5 \%$ of the patients underwent only one surgical procedure per stage and only $11.5 \%$ performed associated operations in the same surgical procedure. We usually do not recommend and do not associate surgical procedures, except in selected cases, after careful analysis of clinical, nutritional, emotional and social conditions. We also advocated and prioritized non-pharmacological preventive management for deep venous thrombosis by reduced surgical time, early ambulation, and good preoperative patient preparation. Another important factor that may have contributed to a lower rate of complications was the low presence of comorbidities at the time of repairing plastic surgery. Coon et al. ${ }^{26}$ studied 449 post-bariatric patients with a complication rate of $41.8 \%$; however, the prevalence of systemic arterial hypertension was $44.2 \%$, and diabetes was $22.3 \%$ among its patients. In the same study, more than $50 \%$ of patients who sought plastic surgery had residual obesity, whereas in our study, only $24.4 \%$ had residual obesity at the time of plastic surgery.

We observed a mean total result of the Moorehead-Ardelt quality of life questionnaire of 2.18, that is, body contouring surgery improved quality of life in more than $90 \%$ of our patients.

\title{
R E S U M O
}

\begin{abstract}
Objetivo: avaliar o perfil de pacientes submetidos à cirurgia plástica pós-bariátrica no Hospital Regional da Asa Norte, Brasília, DF. Métodos: estudo prospectivo, descritivo e analítico de pacientes submetidos à gastroplastia em Y- Roux e, posteriormente, à cirurgia plástica, no período de janeiro de 2011 a dezembro de 2016. Foram avaliados o índice de massa corporal antes da gastroplastia e depois da cirurgia plástica, as complicações pós-operatórias e as comorbidades. Resultados: foram estudados 139 pacientes (130 mulheres e nove homens) com média de idade de 41 anos e submetidos a 233 operações. O IMC médio no momento da cirurgia plástica foi de $27,44 \mathrm{Kg} / \mathrm{m}^{2}$. A média de perda de peso foi de $47,02 \mathrm{Kg}$ e a média de IMC máximo foi de $45,17 \mathrm{Kg} / \mathrm{m}^{2}$. O tempo médio entre a cirurgia bariátrica e a cirurgia plástica foi de 42 meses. As comorbidades antes da cirurgia plástica mais importantes foram: hipertensão arterial $(11,5 \%)$, artropatia (5,4\%), diabetes mellitus (5\%) e síndrome metabólica $(4,3 \%)(p<0,01)$. Dos 139 pacientes operados, 76,97\% foram submetidos à abdominoplastia seguida de mamoplastia (42,46\%), ritidoplastia (17,27\%) e braquioplastia (13,67\%). Quatorze (13,08\%) pacientes foram submetidos à herniorrafia combinada à abdominoplastia. Abdominoplastia em âncora foi feita em 19,42\%. A taxa de complicações pós-operatórias foi de $26,65 \%$. Conclusão: o perfil epidemiológico dos pacientes pós-bariátricos que foram submetidos a cirurgia plástica foi semelhante ao relatado na literatura, exceto pela baixa taxa de cirurgias associadas e complicações pós-operatórias. A cirurgia plástica nos pacientes pós-bariátricos gerou uma melhora da qualidade de vida na maioria desses pacientes.
\end{abstract}

Descritores: Cirurgia Bariátrica. Cirurgia Plástica. Abdominoplastia. Complicações Pós-Operatórias.

\section{REFERENCES}

1. Barros F. Qual o maior problema de saúde pública: a obesidade mórbida ou a cirurgia bariátrica no Sistema Único de Saúde? (Parte I) [editorial]. Rev Col Bras Cir. 2015;42(2):69.

2. Buchwald $H$, Avidor $Y$, Braunwald E, Jensen MD, Pories W, Fahrbach K, et al. Bariatric surgery: a systematic review and meta-analysis. JAMA. 2004;292(14): 1724-37. Erratum in: JAMA. 2005;293(14):1728.
3. Longitudinal Assessment of Bariatric Surgery (LABS) Consortium, Flum DR, Belle SH, King WC, Wahed AS, Berk P, Chapman W, Pories W, Courcoulas A, McCloskey C, Mitchell J, Patterson E, Pomp A, Staten MA, Yanovski SZ, Thirlby R, Wolfe B. Perioperative safety in the longitudinal assessment of bariatric surgery. N Engl J Med. 2009;361(5):445-54.

4. Kitzinger HB, Abayev S, Pittermann A, Karle B, Kubiena $H$, Bohdjalian $A$, et al. The prevalence of body contouring surgery after gastric bypass surgery. 
Obes Surg. 2012;22(1):8-12.

5. Ramalho S, Bastos AP, Silva C, Vaz AR, Brandão I, Machado PP, et al. Excessive skin and sexual function: relationship with psychological variables and weight regain in women after bariatric surgery. Obes Surg. 2015;25(7):1149-54.

6. Karlsson J, Taft C, Rydén A, Sjöström L, Sullivan $M$. Ten-year trends in health-related quality of life after surgical and conventional treatment for severe obesity: the SOS intervention study. Int J Obes (Lond). 2007;31(8):1248-61.

7. van der Beek ES, Geenen R, de Heer FA, van der Molen AB, van Ramshorst B. Quality of life long-term after body contouring surgery following bariatric surgery: sustained improvement after 7 years. Plast Reconstr Surg. 2012;130(5): 1133-9.

8. Obesity: preventing and managing the global epidemic. Report of a WHO consultation. World Health Organ Tech Rep Ser. 2000;894:i-xii, 1-253.

9. Sociedade Brasileira de Endocrinologia e Metabologia. Sobrepeso e obesidade: diagnóstico. Brasília (DF): Associação Médica Brasileira; Conselho Federal de Medicina; 2004.

10. Silva CF, Cohen L, Sarmento LA, Rosa FMM, Rosado EL, Carneiro JRI, et al. Efeitos no longo prazo da gastroplastia redutora em Y-de-Roux sobre o peso corporal e comorbidades clínico metabólicas em serviço de cirurgia bariátrica de um hospital universitário. ABCD Arq Bras Cir Dig. 2016;29(Supl 1):20-3.

11. Sociedade Brasileira de Cardiologia; Sociedade Brasileira de Hipertensão; Sociedade Brasileira de Nefrologia. [VI Brazilian Guidelines on Hypertension]. Arq Bras Cardiol. 2010;95(1 Suppl):1-51. Erratum in: Arq Bras Cardiol. 2010;95(4):553. Portuguese.

12. Oria HE, Moorehead MK. Bariatric analysis and reporting outcome system (BAROS). Obes Surg. 1998;8(5):487-99.

13. de Kervilier S, Hüsler R, Banic A, Constantinescu MA. Body contouring surgery following bariatric surgery and dietetically induced massive weight reduction: a risk analysis. Obes Surg. 2009;19(5):553-9.

14. Coon D, Michaels J 5th, Gusenoff JA, Purnell C, Friedman T, Rubin JP. Multiple procedures and staging in the massive weight loss population. Plast
Reconstr Surg. 2010;125(2):691-8.

15. Arthurs ZM, Cuadrado D, Sohn V, Wolcott K, Lesperance K, Carter P, et al. Post-bariatric panniculectomy: pre-panniculectomy body mass index impacts the complication profile. Am J Surg. 2007;193(5):567-70; discussion 570.

16. Orpheu SC, Coltro PS, Scopel GP, Saito FL, Ferreira MC. Cirurgia do contorno corporal no paciente após perda ponderal maciça: experiência de três anos em hospital público secundário. Rev Assoc Med Bras. 2009;55(4):427-33.

17. Donnabella A, Neffa L, Barros BB, Santos FP. Abdominoplastia pós cirurgia bariátrica: experiência de 315 casos. Rev Bras Cir Plast. 2016;31(4):510-5.

18. Parvizi D, Friedl $H$, Wurzer $P$, Kamolz LP, Lebo $P$, Tuca $A$, et al. A multiple regression analysis of postoperative complications after body-contouring surgery: a retrospective analysis of 205 patients: regression analysis of complications. Obes Surg. 2015;25(8):1482-90.

19. Masoomi H, Rimler J, Wirth GA, Lee C, Paydar $K Z$, Evans GR. Frequency and risk factors of blood transfusion in abdominoplasty in post-bariatric surgery patients: data from the nationwide inpatient sample. Plast Reconstr Surg. 2015; 135(5):861e-868e.

20. Vilà J, Balibrea JM, Oller B, Alastrué A. Post-bariatric surgery body contouring treatment in the public health system: cost study and perception by patients. Plast Reconstr Surg. 2014;134(3):448-54. Erratum in: Plast Reconstr Surg. 2014;134(6):1436.

21. Shermak MA, Chang D, Magnuson TH, Schweitzer MA. An outcomes analysis of patients undergoing body contouring surgery after massive weight loss. Plast Reconstr Surg. 2006;118(4):1026-31.

22. Ferraz EM, Arruda PCL, Bacelar TS, Ferraz $A A B$, Albuquerque $A C$, Leão CS. Tratamento cirúrgico da obesidade mórbida. Rev Col Bras Cir. 2003;30(2):98105.

23. Novais PFS, Rasera Jr I, Leite CVS, Oliveira MRM. Evolução e classificação do peso corporal em relação aos resultados da cirurgia bariátrica: derivação gástrica em Y de Roux. Arq Bras Endocrinol Metab. 2010;54(3):303-10.

24. Schmid H, Goelzer Neto CF, Dias LS, Weston AC, Espíndola MB, Pioner SR, et al. Metabolic syndrome 
resolution by Roux-en-Y gastric bypass in a real world: a case control study. Rev Assoc Med Bras (1992). 2015;61(2):161-9.

25. Lopes EC, Heineck I, Athaydes G, Minhardt NG, Souto $K E$, Stein $A T$. Is bariatric surgery effective in reducing comorbidities and drug costs? A systematic review and meta-analysis. Obes Surg. 2015;25(9):1741-9.

26. Coon D, Gusenoff JA, Kannan N, El Khoudary SR, Naghshineh N, Rubin JP. Body mass and surgical complications in the postbariatric reconstructive patient: analysis of 511 cases. Ann Surg. 2009;249(3):397-401.
Received in: 20/11/2017

Accepted for publication: 04/01/2018

Conflict of interest: none.

Source of funding: none.

\section{Mailing address:}

Simone Corrêa Rosa

E-mail: scrmacedo@yahoo.com.br /

jlsmacedo@yahoo.com.br

\section{(cc) BY}

